\title{
Investigating Arman Shahr in Asi's Poems
}

DOI: https://doi.org/10.47175/rielsj.v2i3.336

\section{| Imamuddin Ibrahimi ${ }^{1}$ | Habibullah Haqiqat ${ }^{2, *}$ | Shafigullah Shafaqat ${ }^{3}$ |}

1,2,3 Senior Teaching Assistant, Department of Farsi Dari, Education Faculty, Paktia University

${ }^{1}$ imamuddinibrahimi222@gmail .com

${ }^{2}$ qnajeebullah@ymail.com

\begin{abstract}
When the grief around the poet and writer is fragile and when life is filled with sorrow and bitterness, then tyranny and oppression become the ordinary profession of the people in several cases; creator, literary and artistic works as a conscious and connected stratum of society do not became the only spectators, instead with the help of transcendent thoughts and creative minds, they create a valuable creation to be mirror of the dreams and desire of people. On the other hand, they reflects the loud sounds in the face of oppression. Sometimes, the poet and writer thinks calmly in the order to get out of the misfortunes. He takes on idea plane in his mind and throw it. It is the form of al-fadh which the term utopia is more suitable to clarify it. The present study reflects the ideas of the Utopia of Abdul Qahar Asi, the contemporary poet of Afghanistan. In this research, it is tried to identify clear examples of the poet's word to explain the ideal reading, expression, the dimension and angles of the poet's utopia. In the continuation of this research, we come to the conclusion that a poet lived in the darkest political situation in Afghanistan who composed a poem and built on utopia to relieve his plan and sorrows. The main indicators of the utopia are the issue of humanity, peace, and love. What he hates and does not want to be in his utopia are war, discrimination, injustice, poverty and selfishness.

KEYWORDS

Utopia, rebellion; war; freedom; love
\end{abstract}

\section{INTRODUCTION}

Without any doubt, poetry is means of influence to express and impose the thoughts of poet. Persian poetry cannot be far from this feature. Sometimes, a poet thinks wishfully and makes the life to be based on it. This mental design is called "Utopia" and the word utopia means ideal city. In the terminology of its term, it is a society which its inhabitants live in perfect condition. It is untrainable place that has been imagined on the horizon of human desire as a good example of beauty and salvation (Toghyanee \& Maeeni, 1387). It is also has been said that the society is above all in which all things are according to the intended purposes or a society where is not news of oppression and discrimination. There are no signs of strife, traces of ignorance and poverty can be found. The society which is ruled by goodness and prosperity (Ahmad \& Zamani, 1390). This type of society is equivalent to the Greek word "Utopia" which is made and paid by Tomas Moor. Utopia itself is derived - from the root meaning "Nothingness" (Moore, 1387). The Persian and Arabic equivalents of "Utopia" that have been used means the city of "Saeedeh" or prosperous, "Nakuga- Abad" or nowhere and the city off "Al- Emkan" or ideal city.

The utopia also has a contradictory meaning in which there are disorder, darkness and bitterness waves; just as in utopia there is talk of good and beauty. The opposite of utopia is talk of evil and ugliness and the concept of utopia under titles such as anti -utopia or 
dystopia. The utopia is an obfuscation king of city. Farabi has called it the area of Medina ignorance which is against utopia. It is an inverse in which perfection and ultimately leads to its opposite. It means perpetual an espionage, suspicion, submission to coercion and etc.. which prevails over the goal (Jahadi, 1394, pp.249). In Islamic culture, instead of the word utopia Ghola is used against utopia instead that there is none utopia cities and these cities themselves find various items such as the essential, Nazaleh, miserly and vain utensils (Ramin, 1398, pp.62).

The literature that is at the service of these debate is called a utopia literature which is used for any philosophical, religious and political fictions (Mer Sadiq, 1377, pp.7). The statement of problem that human are surrounded by the suffering of life and when the adversity of time seized him; then in order to save themselves from inner contract, sorrow and pain; they start building an utopian who expect to live in peace. Asi is one of the poets who spent his life in war and hilling and he has heavily burden of persecution and pain.

The life of this poet is gloomy, dark and his life is without salt and beauty. Therefore the idealism is reflected from his poems. This research tries to hand some component reexamined the idealism of Asi`s poet and on the other hand pillars show utopia on his poems.

\section{RESEARCH METHODS}

There is no doubt that to study utopia, the Persian poets have written more book and articles in Iran and other places; but in territory of Afghanistan no significant research work has been done in this field. According to surveys, enough scholars are presented but it seems that no much research has been done on Asi`s poems in the field of idealism. But still, there has been some pieces of writing, the crystallization of freedom in Asi S poems which have been indicated in writing by DR. Ishaq Toghyani and Muhammad Tahir Fayaz, who explored the concept of freedom in Asi,s poems. There is no doubt that freedom is one of the elements of Asi's utopia that studies and analyses the manifestation of resistance and stability.

\section{Questions of Inquiry:}

The basic questions which have been tried to be answered are as following:

- Are Asi's writings assessable and analyzable based on Arman Shahr?

- What are the most important Ennobling points in Aasi`s poems?

\section{RESULTS AND DISCUSSION Investigates}

\section{Who is Abdul Qahar Aasi?}

Abdul Qahar Aasi is son of Abdul Manan, one of the well-spoken and talented poet of Persian language. He was born in 1335 Hijri in Malimah village of Pangshir provenceo in Afghanistan. He has completed his primary education in his village and completed his secondary in Ghazi High School in Kabul. He succeeded in Agriculture Faculty of Kabul University and then graduated from the faculty in 1362. After the graduation, he got a job as a territorial reform agent in Ministry of Agriculture in the country. Aasi has been interested in writing poem and curtsey from the very beginning at childhood. It has caused his familiarization to Persian poets such as Wasifi Bakhtar, Haidary Wojodi, Azim Herati and others. These peots open doors to him toward poets world who become very famous in this filed (Karimi \& Aryan, 394, pp.164)

Aasi has started poem writing when the situation was tough and under colonization of Soviet Union in Afghanistan. All materialistic and spiritual existence of the country were 
in distraction and there was no attention to the culture and curtsey. In such situation, every person is hugging in making his wishes world to sooth his pairs and sorrow in Aasi's poems. We can see this too, and a world that the poet likes for himself and others. Aasi has got habit with situation where he has been living in his homeland. Aasi was dominant in speaking English and Urdu language very well. He has changed the poems of Ghalib Ghulam Mustafa, Professor Mohammad Baqir and Parwin to Persian. There are many great and new pieces of Aasi that has not published yet such as Bedal Shinasi about Specter of Art and Anthropology in Logar, Old Words of Persian in Panjshir, Spicy but Dust and Notify from Vally to Lie are amongst them (Qawim, 1393, pp.151).

Aasi had short life and couldn't find chance for more work. Besides, he invocated and writing big treasures of poems to people. He has published his first completing of poems under the name of "Maqame Gul Sari" in 1367, "Lalaie to Malime" in 1368, "Dewan Aushiqan Bagh" in 1969, a total of sonnet under the name of "Man O Ghame Man) in 1370, "Alone but Permanent" in 1370, and "Jazera Khon" in 1371. Two of his collections have been published by Islamic Community and his writer friends in Germany in 1374 and he passed away in 1373 (Toghyani \& Fayez, 1397, pp. 246). In the progress, we are going to focuse to clarify Aasi's indexes Arman Shahr from two dimensions: the realities of the society or Abominable and wishes of the poet.

\title{
Realities of the Society (Abominable):
}

War: War brings destruction and faces all material and cultural resources of society to misery. When human become ill natured, he tries to get power to involve in war. As it is said about war, which in war is someone tries to impose it right toward others (Ahmadi \& Zamani, 1390, 39). Aasi was living in a time that war was going on everywhere. He was seeing that it was taking soul of his country and changes it to dust. He has pointed to this subject in his poem:

\author{
Killer of my city ---- Killer of my city \\ killing of sucks ---- Sang of his killing \\ Comes with no music chair of bleeding \\ Knows no mooring and no evening \\ In my city killer from blast of missile and rocket \\ On head of mother takes their fortune and luck
}

(Kolyat: 454)

Long and progressively war made the situation very bad that every person appears as rioter to Aasi and he trusts no one.

Whose hand we can pressure?

As trust in a city

That words has changed colors

That alif means fire and be means barood

War has taken beauty of every thing

Garden doesn't have greenness and spring doesn't have pure weather

And lovely weather looks sad

$$
\text { بار از وطن خودش فر ارى شد ورفت }
$$

Finely, war causes killing and bleeding which has taken neuter from his country's name. 


$$
\begin{aligned}
& \text { نوشتم قصه اى غم نوشتم بلاى انفجار و بم نوشتم }
\end{aligned}
$$

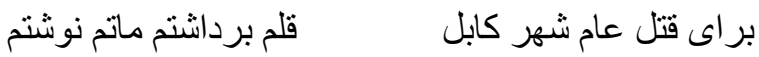

Unkindness: Unkindness intimacy are Aasi's the biggest wordiness and his sufferings. He was counting it as mirage.

$$
\begin{aligned}
& \text { روزى كه مهربانى زين جا كذر كند روزى نماز و سور است آن روز اكربيايد }
\end{aligned}
$$

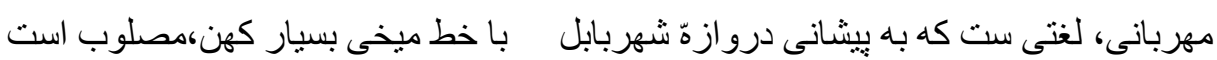

He is mentioning in another place that kindness and love has died from this area and has shaken small door of this yard.

Prejudice: It is the worst quirks that spotted skirt of humanity and there is no doubt that humans speak with different languages. They are belays to different tribes and even their geographical life are different which these things must not pave the ground to prejudice. Prejudice is something to counts his language better than others. It was the times which Aasi was living the fire riot was very flammable and boggiest fights occurred due to this. Therefore, the poet become score and conceded that in making fire there are other hades.

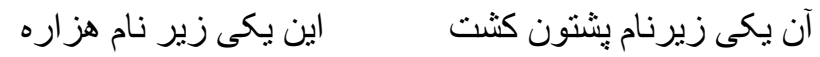

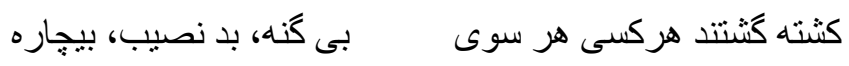

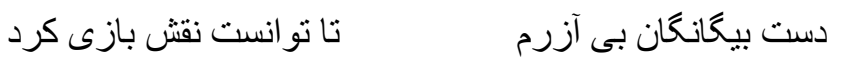

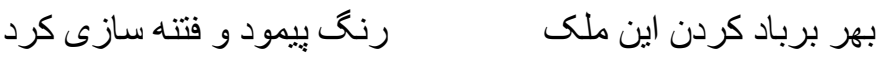

Aasi in "Qalam Nomah" emphasized that every nation and language inducible part of society that is not good to count one better than the others and it is impossible to rotate a tribe or language.

Insulting: 1370 wasn't a good year for poet because it destruction has increased and become much more. Besides, people have been killed by deferent title and divided to deferent part so that they their goals criticized by poet. It was not fault of the year but the aim of Aasi was people who have done the crimes.

$$
\begin{aligned}
& \text { سال ذلت،سال خوارى سال نامه ،سال زارى }
\end{aligned}
$$

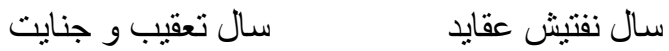

$$
\begin{aligned}
& \text { سال تو هين و شدايد سال تخقير و تحقير و تمسخر } \\
& \text { ( كليات : ه (ه) }
\end{aligned}
$$

Autonomy: We may not able to find the worst but here then cruelty and auto verity among crater and this grow in the human body. It changes a human to origin of evil and auto crafty human changes as a feral of their times to others. Aasi has a series of steps again and count them a dirty secret furrow and colored donkeys.

$$
\begin{aligned}
& \text { زفتنه فكندند هرسوى كين بر اي رياست نه از بهر دين } \\
& \text { همه كلها خشا خـ و دل ها سياه همه سينه ها كنده و كينه كاه }
\end{aligned}
$$

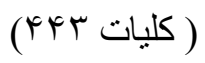


Brutality: Aasi grew as a child that some people become famous due to their crimes and small people had been killed among their paws. Kindness and love gave their places to unkindness. Love has gave from homeys as Raziq said: "No one takes care of others in our society--Deer sell its kind to tiger". In other of enemy becomes brother Aasi says in other place that he suffers the fear his times in pain, sorrow and gathering buries of their brothers without any problem. Aasi because of all these issues has lost his laughs.

$$
\begin{aligned}
& \text { شب را كريستم،سحر را كريستم ما كَام كام ر اه سفر را كريستيم }
\end{aligned}
$$

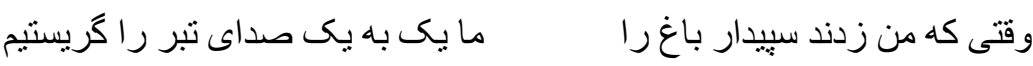

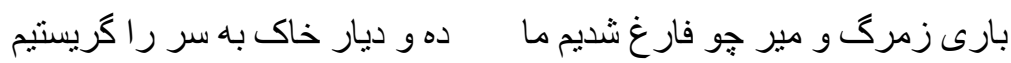

$$
\begin{aligned}
& \text { مضمون كريه كم نشد از دور و بِيبٍ ما هر جند كه بلا و بتر را كريستيم }
\end{aligned}
$$

(73: (كليات)

Aasi compared the society and environment to Karbala Desert of Iraq due to fumes cruelty and killing.

$$
\begin{aligned}
& \text { طبل كثنار مزن فتنه مران اى قاتل بيش ازين خيره مشو كور مخوان ای قاتل } \\
& \text { كس نمانده است در اين واد دوزخ بى غم تو د كر بس كن و آتش مفشان اى قاتل } \\
& \text { خون يك شهر رعيت همه بركردن توست ملتى از تو به فرياد و فغان ایى قاتل }
\end{aligned}
$$

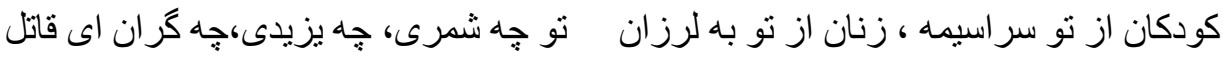

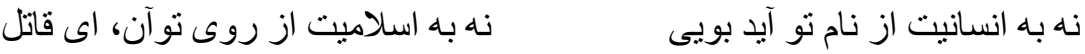

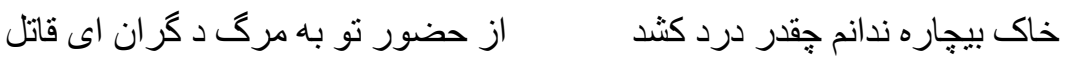

$$
\begin{aligned}
& \text { تو ميكويى اى مجرى برنامه شمر كربلا خبث تر اكرده عبان از قاتل }
\end{aligned}
$$$$
\text { ( }
$$

Injustice: When justice goes away from society, cruelty starts, right of people wastes and more blood bleeds. In Aasi`s time, the war was in progress and the injustices level and the right of innocents were under feet. He was crying for this conditions and fishes were the symbol of cruel humans.

Violence: Grouch acerbity and evidence are both behavior of human that cause space between humans and ramous fondness from human's heart. When violence increases in a society, goodness and humanity dies. Aasi is a poet that focuses on planting friendship tree and calls people to leave violence.

$$
\begin{aligned}
& \text { زدين آنجه دارند ريش است وبس از انصاف، جور هميش است وبس }
\end{aligned}
$$

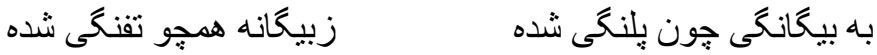

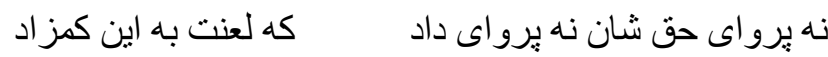

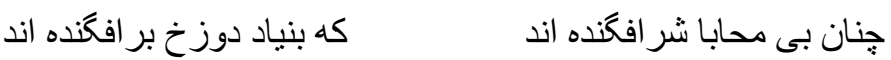

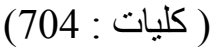

In a poem to killer of Kabul and those who creates dread and makes evidence condemns them in a hard language and put himself in place of poor people and cries. 
Poverty: Aasi in his poem under the name of (Hungriest) decks about bad situation of lounger and poverty to display the condition of girls, youths, mothers and other people of society.

\section{Moments repeat with \\ Two sounds of pains affected}

10 to 12 years old mothers from deliveries loud kids

Kids yelling for bread their mats are within fluent 20

Skins dark disappointed from all

They are just dreaming they are just yelling bread

Aasi in "Prophetic" poets complain the pain of people to the prophet and complains from bad situation of people to prophet.

$$
\begin{aligned}
& \text { كودكان از فقر، اندرين وادى روبه نوميدى، روبه بربادى } \\
& \text { خو اهر ان از سوخ،آه و فرياد مادر ان در خون، جامعه و معجر }
\end{aligned}
$$

Duplicity: The result of honesty is actually similarity on the other side while Ria is duplicity (Piroz, 1394, PP.663). In that time, Aasi honesty changed to dishonesty that is why he was disgusted from duplicity and was taking people away from it.

$$
\begin{aligned}
& \text { زندگى دشوار وسير غربتش دشوارتر درد بسيار است و تنهايى در آن بسيار تر } \\
& \text { جهر ها مسخ اندودلها سخت تر در جنبش اند حرفها آلوده تر آينهها بيمارنز } \\
& \text { (كليات:573) }
\end{aligned}
$$

In the poem of "Let's Laugh", he laughed at the policy of world against Afghanistan and trusted that the assertion of humanitarian of them is not honestly. Let's laugh to western peace plan, to clear goodness of America, to the condition of ridiculous. Let's laugh to goodness of bush to their fellow supporters.

\section{Aasi's Wishes}

Humanity: As much as the human develops, they become that much aggressive. From the other side, today's human forgot his or her position and identity for the sake of technology developments. Aasi believed on humanity regions and doesn't know better values then it. As he was living in a war condition, he knew that sometime human changes to animal. We can see this habit war in warriors' eyes. Aasi is counting human as a big capacity and home of love and kindness

$$
\begin{gathered}
\text { Hey! Sun! } \\
\text { Bigger capacity of human } \\
\text { Have you seen in humanities station this trust? } \\
\text { Sometimes God and love } \\
\text { Today wrest then always } \\
\text { (Kolyat 478) }
\end{gathered}
$$

When battle happens for special proposes, bad people don't care of values they take pleasure from funk and enjoy from killing and looting.

$$
\text { زهر خانهيى ماتمى سركثيد به هر كوجه فتاده صدها شقيد }
$$




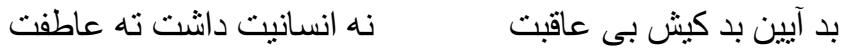

$$
\begin{aligned}
& \text { كلو له فروريخت فاشيست وار بشد زخمى و كثته بـشمار } \\
& \text { نشان داد فر هنگ خودر ازبون به جنى بر ادر كثى وخون } \\
& \text { از انسانيت غير وحشت نداشت وز اسلاميت غير دهشت نداشت }
\end{aligned}
$$

(كليات : 444$)$

Aasi says those who spreads war and violence on earth they are out of humanity sense .

$$
\begin{aligned}
& \text { فروشست جنكيزه وبرد ايغار } \\
& \text { از از بدتر انسان نديديم ما } \\
& \text { كه سر رشته نظم از هم كسيخت } \\
& \text { هز اران ديكر به خون عشته شد }
\end{aligned}
$$

$$
\begin{aligned}
& \text { جنان كشت كزحافظه روز } \\
& \text { خلاصه كه روى زمين } \\
& \text { كه جندان بدين شهر آتش ريخت } \\
& \text { هز ار ان نن از مسلمين كثته شد }
\end{aligned}
$$

(كليات : (447)

Peace: We can't find clear space then peace every one wishes to live in peace. Besides, we can see dark minded people that they see their benefit in war and conflicts. Aasi has invited people to unity.

$$
\begin{aligned}
& \text { غريق را به غلط نا خدا مينداريد غبار را علم اعتماد مشماريد } \\
& \text { به خط جبهه منصور مرد كار شويد زهرجه بيشتر ايمان به خويشتن آريد } \\
& \text { به بِاى خود بكزينيد ر اهوجاه سفر به دست كمشدهى اختيار مسياريد } \\
& \text { هنوز تاكه جر اغى و خنجرى يبداست زگُشه كَّهـ اسن سفره سهم برداريد }
\end{aligned}
$$

(كليات:572)

There is a famous proverb that a flower can't make spring. It means that being separated can cause salvation so we have to make all garden green he means we have to be united.

$$
\text { من از شكفتن يك شاخته كل نمى شخفتم مر ا طر اوت يك كوشه كرد كافى نيست }
$$

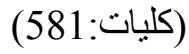

Love: Human life take fountain from love; as Hafiz says the heart which doesn't have love call it heart of animals. We have to love to spirituals, human, sense and to the beauty of creature. Love is one of the life's cycle. The poets have different views regarding it and broadcoasted their ideas regarding love. ( Farzad \& Muradi Jafar,1394, PP1552 ).

$$
\begin{aligned}
& \text { عشق را فرمان روا و خويش را فرمانكذار } \\
& \text { كار يك هنحامه را از اين دست آسان كرده اند }
\end{aligned}
$$

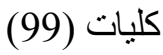

Treats: Aasi lovers to prophet of difficult times lovable mans are the prophets of future bad and dark days ( Kolyat 99 ). Aasi counts the word of love sweat phrases and counts himself a lover. Our poet had deep love with witty too and love waves in each of his vines. 
Freedom: Freedom is a big favor and lovely value for creation. Every human born free, loves freedom and tries in saving it. Those who takes freedom from people, they are called rapist and oppressor. Poets who have high home loving moral and freedom soul, their sounds are sound of freedom. Freedom for Aasi is like wetness that people turns around it like fly who turns candle. As Partaw Naderi said that freedom is like missed idea in Aasi's poems. When freedom is in sorrowed, loses its context. Aasi written 8 poems in regarding freedom in his "Lovely Garden" total like swan to its couple and like thirsty to water that think about you.

(Kolyat 221)

$$
\begin{aligned}
& \text { بوى كل زمزمه باد بهار آز ادى عثق من آينه قامت يار آزادى } \\
& \text { كوكوى فاختهها همهمه ماهى ها } \\
& \text { خشم قومى به سر افر ازى صدها رستم ارث آبايى من داروندار آز ادى }
\end{aligned}
$$

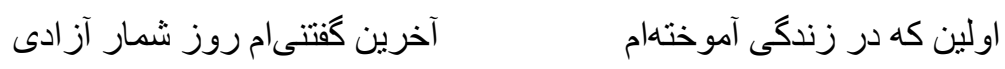

$$
\begin{aligned}
& \text { (كليات:93) }
\end{aligned}
$$

He was raising sound of freedom everywhere. It was waving in his vine, blood and he drank from wine of freedom. Aasi advices to erasure the freedom word everywhere. So, it can bee see always and can set to ideas so not to be forgotten.

Honesty and homochromatic: Aasi is looking to someone honestly in a situation that the sad world and its people sink in sedation of disunity. He searches those people who can play positive role and love people having kindness and actually be real human.

$$
\begin{aligned}
& \text { عاثقى خو اهم كه دل درياى دريا باشدش عثق دست و عثق باى و عشق دنيا باتشدش }
\end{aligned}
$$

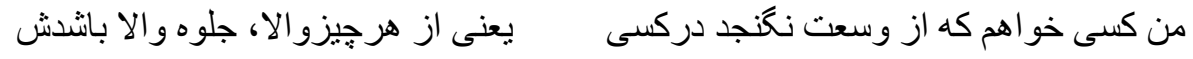

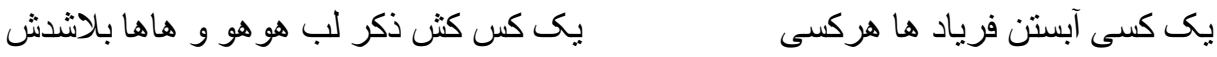

$$
\begin{aligned}
& \text { يك كسى مانند من، مانند تو، ماننو او ليك ايمان وفا محكمتر از ما باشدش } \\
& \text { (كلبات:570) }
\end{aligned}
$$

\section{CONCLUSION}

Abdul Qahar Aasi (1335-1373) is one of the well-spoken of modern Farsi in Afghanistan. He has lived and had his activities in war and in emigration times. He is the best poet in resistance time because his poems are lyrics, political, social and other topics. During the inquiry, we have found that he has tried and struggled for making "Arman Shahr" which the space of Arman Shahr is full of love, honesty, kindness and freedom. He also prefers justice for the residents of his area. He believes that when peace comes, we can have justice. He also emphases on peace and reconciliation and hates war prejudice, dishonesty, poverty and Ria. He stood against all these and raised the voice of freedom which is the main part of "Arman Shahr" in his Kolyat. There are many poems that pointed these subjects.

I become happy from the smell of four wine, freedom I called you from the middle of my paternal temple freedom!

Oh caravan of love and enjoyment

Oh! Green wishes cities freedom!

Oh Freedom! 


\section{REFERENCES}

Ahmadi, Jamal and Zamani, Sara. (1390). Utopia in the Poems of Fereydoun Moshiri, Quatery Journal of Educational and Lyrical Research in Persian Language and Literature, Islamic Azad University, Bo Shahr Branch, No. 9.

Asi Qahar. Generalities of Qahar Asi, by Nilab Rahimi, Kabul Khayyam Publications.

Farzad, Abdulhissein and Moradi Jaferloo, Somayeh and Moradi Jaferloo, Younes. (1394). Investigating the concept of love in Ahmad Shamloo utopia. 8th Persian Language and Literature Research Conference.

Fazaeli, Hassan. (1383). The Impact of Afghanistan`s Political and Social Military on Dari Literature, Qom, Strategic Studies and Research.

Jihadi, Sayed Amir. (1394). Study and analysis of the utopia in the thought of the Third Brotherhood, a collection of articles from the 10th International Conference on the Promotion of Persian Language and Literature at Mohaghegh Ardabili University.

Karami, Mohammad Hossein and Arian, Nasir Ahmad. (1394). A study and Analysis of the Manifestations of Resistance and Stability in the Poetry of the Contemporary Afghan Poet Asi, Journal of Sustainability Literature, Shahid Bahonar University of Kerman, No.12.

Moore, Thomas. (1387). Utopia Translated by Dariush Ashouri and Nader Afshar Naderi, Tehran, Kharazmi Publications.

Mir Sadighi Jamal and Mir Zulqader, Meymanat. (1377). Artistic Dictionary of Fiction Writing (Detailed Dictionary of Fiction Literature Terms), Tehran, Mahnaz Publications.

Naderi, Parto. (1399). Poetry of Sustainability and How in Afghanistan, Kabul Saeed Publications.

Nemati, Farooq. (1391). In the Nowhere (Comparative Study of Utopia in the Poetry of Gibran Khalil Gibran and Sohrab Sepehri) Quarterly Journal of Persian Language and Literature, Islamic Azad University, No. 12 .

Pirooze, Ghulamreza and Salamat Ahangari, Mansoureh. (1395) The effects of idealism in the poetry of Qaisar Aminpour, a collection of articles from the 10th International Conference on the Primotion of Persian Language and Literature, Mohaghegh Ardabili University.

Qawim, Abdul Qayoum. (1393). A Review of Dari Contemporary Literature. Kabul Saeed Publications.

Ramin, Farah. (1389). The structure of Knowledge in Moore`s utopia culture and Mahdsvi utopia, Mashreq Mo`oud Scientific- Research Quartery, No. 13.

Toghyani, Ishaq and Fayez, Mohammad Zahir. (1397). Crystallization of freedom (Azadi) in Asi Utopia, Journal of Sustainability Literature, Shahid Kerman University, No. 19.

Toghyani, Ishaq and Moeini Fard, Zahra. (1387). Utopia of women in Khosrow and Shirin Hakim Nezami Ganjineeha!, Journal of Lyrical Literature, Sestan and Baluchestan University, No. 11. 